\title{
Luis de Sebastián y Jon Sobrino, dos lenguajes diferentes, una misma denuncia: la deshumanización
}

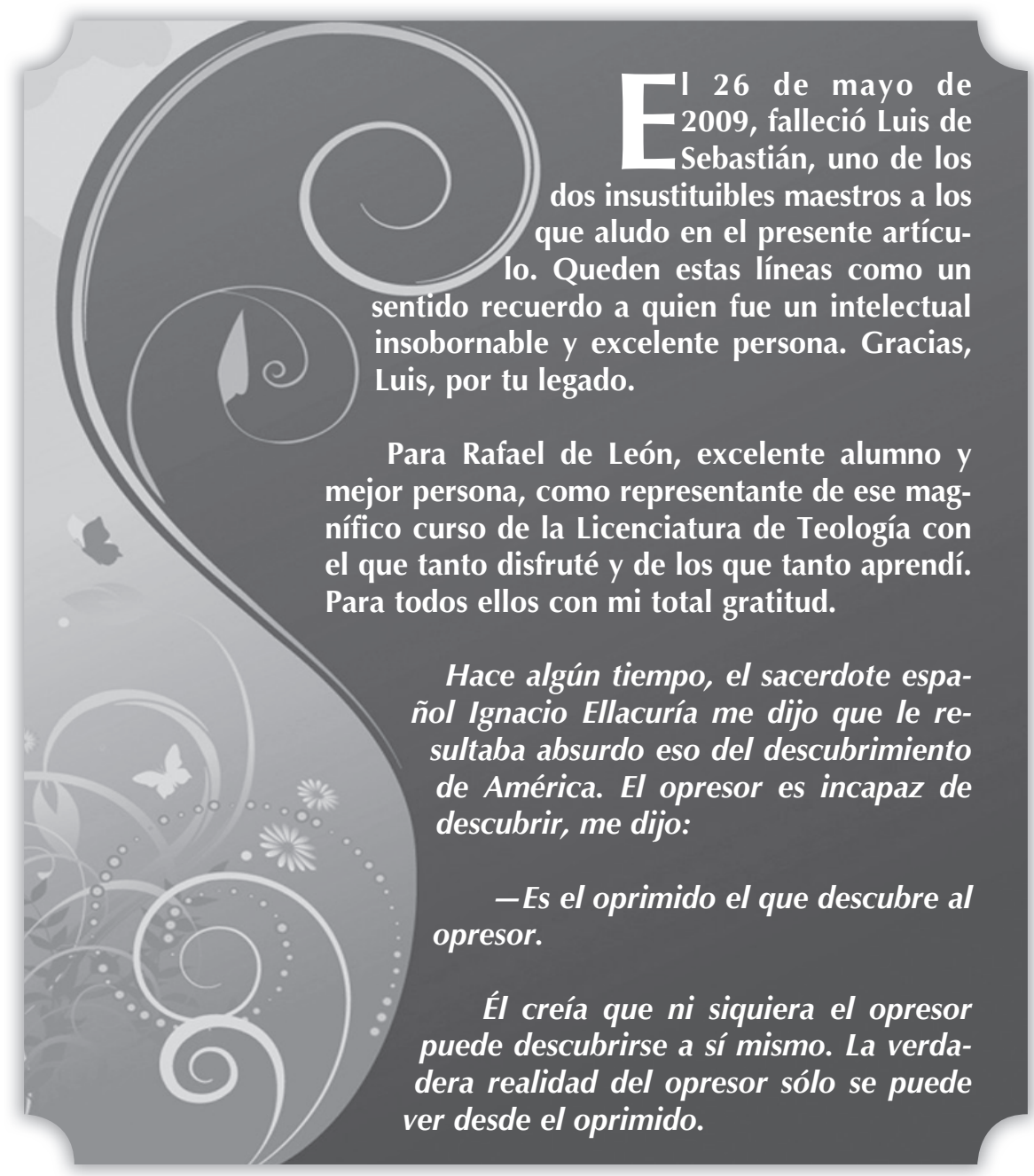

Luis de Sebastián y Jon Sobrino, dos lenguajes diferentes, 
Ignacio Ellacuría fue acribillado a balazos por creer en esa imperdonable capacidad de revelación y por compartir los riesgos de la fe en su poder de profecía.

¿Lo asesinaron los militares de El Salvador o lo asesinó un sistema que no puede tolerar la mirada que lo delata?

Eduardo Galeano, Ser como ellos

\section{Introducción para idiotas}

"La vida te da sorpresas, sorpresas te la vida... ¡Ay, Dios!" Seguro que recuerdan el final de la canción Pedro navaja del panameño Rubén Blades. No sé si se han detenido a pensar en la profundidad de estas palabras. Yo debo confesar que no lo había hecho y lo estoy pagando caro, muy caro. Me explico. Resulta que yo tengo pasaporte de la Comunidad Europea —soy nacido en España mientras no se demuestre lo contrario- y por lo tanto, aquí soy un extranjero —vamos, un extraño— al que no le queda más remedio que ir empapándose de la realidad, en este caso, salvadoreña. Pues bien, estaba completamente equivocado. Resulta que padezco una profunda crisis de identidad: no sólo soy latinoamericano, sino que además, soy un "perfecto idiota". En resumen, que doy el tipo para ser reconocido como un perfecto idiota latinoamericano. ¿Cómo lo he descubierto? Gracias a la conspicua inteligencia de tres cerebros, éstos, sí, latinoamericanos: Plinio Apuleyo Mendoza, Carlos Alberto Montaner y Álvaro Vargas Llosa. Les cuento.
El caso es que durante las vacaciones de agosto pasadas tuve la gratísima experiencia de leer dos libros que realmente me impactaron: África, pecado de Europa de Luis de Sebastián, y Fuera de los pobres no hay salvación de Jon Sobrino, ambos publicados por la editorial española Trotta. Y la verdad, perdónenme que me repita, el impacto fue tal que decidí escribir unas líneas sobre ellos. Consideré que sería oportuno documentarme un poco más y para eso nada mejor que enredar en internet. Así que me puse manos a la obra y no sé la razón pero comenzó a aparecer de forma repetida en mi pantalla la obra de los tres autores citados: Manual del perfecto idiota latinoamericano. La obra, por si no lo saben, está prologada por el papá de Álvaro, Don Mario. Este monumento de la literatura apareció en 1996 y aunque recuerdo haberlo visto en las librerías en España, debo reconocer que ni tan siquiera le eché un vistazo. Para qué engañarnos, los apellidos Vargas Llosa no son santos de mi devoción. Le reconozco a Don Mario su capacidad novelística —no tengo ningún 
empacho en reconocer que su novela La fiesta del Chivo (Alfaguara) me cautivó por su sensibilidad hasta el punto de recomendarla-, pero cuando se trata de otros asuntos, políticos o sociales, me aburre. Él mismo reconocía en una entrevista concedida a una revista española $E l$ viejo topo que un escritor no tenía por qué estar acertado en todos sus comentarios. Pues bien, jcraso error el que cometí! ¡Lo que uno puede aprender abriendo por lo menos un texto como éste!: nada más ni nada menos que la significancia de lo insignificante. ¿Que no conoce usted esta maravilla? Pues como le decía, yo tampoco la conocía, pero como está en la biblioteca de nuestra UCA, me abalancé, me arrojé sobre ella. No es exageración, se trataba ni más ni menos que de despedirme de mi idiotez. Ya está en mis manos. ¡Abrámosla!

Siempre he creído que mal de muchos no es consuelo de tontos, sino epidemia, y esto va más allá porque uno tiene la sensación a primera vista de que menos nuestros cuatro iluminados y sus amiguetes, el resto de la humanidad está completamente perdida $y$, lo que es peor, sin remedio o eso parece de entrada.

Para ser justos, no recuerdo que hagan referencia en la citada obra a los yanomami, un grupo que vive en la selva amazónica, pero a buen seguro que en las próximas entregas los veremos integrando la lista. Sí, todo es cuestión de que, como decía, alguno de sus cheros descubra que algo de interés se oculta en ese espacio que ocupa esa tranquila gente que sólo se dedica a vivir. No tiene que ser petróleo o alguna materia prima similar. Imagínense que alguien considera esa ubicación óptima para la construcción de un casino. Esto sería para bueno para el desarrollo turístico de la zona, ¡cómo no! Al principio habría un acercamiento pacífico para que abandonen sus tierras. La respuesta de esta gente nos la imaginamos. El segundo acercamiento sería ya conminatorio y la respuesta sería la misma. Ante semejante desacato, lo normal es que sean declarados terroristas, no quedando más remedio a los constructores del complejo que mandar al ejército de turno para proceder no al desalojo sino a la aniquilación de este peligrosísimo grupo para la civilización. ¿Qué se han creído estos pinches indios? El progreso es el progreso y nadie lo va a detener, ¡hasta ahí podíamos llegar! Pero, como decía, aún no aparecen en la lista, así que tranquilidad por ahora.

¿Considera esto exagerado? Dejémoslo en caricaturesco y ya se sabe que hay caricaturas buenas $y$ malas. ¿Tiene algunos ahorritos y no sabe qué hacer con ellos? Yo no soy experto en inversiones pero si quiere parecerse a los miembros de la alta sociedad, compre su "parcelita" en la Pampa argentina. Sí, como lo oye, está en venta y los adinerados 
compran hectáreas como usted tortillas. Pero no crea que lo hacen por incrementar su patrimonio, sino con fines ecológicos, vamos, para crear parques naturales, y es que tanto los mapuches como los guaraníes, habitantes desde siempre de estas tierras, no saben respetar su propio hábitat. Pero esto no termina aquí. Luciano Benetton ha ido más allá y ha construido el Museo del Mapuche, ya se sabe, para preservar su cultura. No se pierdan unas imágenes difundidas por TVE en las que un grupo de esta etnia, frente al Museo, se preguntaba si el diseñador los consideraba ya extintos. ¡Pero si aún vivimos!, clamaban. El problema es que ya forman parte del batallón de los invisibles. Algunos abogados argentinos -Fernando Kosovsky, entre otros - ya se han puesto manos a la obra y están defendiendo los derechos de estas gentes que ven cómo su tierra, la de siempre, en la que están enterrados sus antepasados, en la que tienen sus raíces, está siendo enajenada por vaya usted a saber quién. Que hay de por medio corrupción o abuso de poder, pelillos a la mar. La ecología y la cultura mandan, y lo demás no es sino volver a un indigenismo ya transnochado y periclitado. En resumen, que denunciar este latrocinio es entrar en el manual del perfecto idiota latinoamericano.

Bien. Avancemos un poco más.

Una vez que usted se haga con este parto de los montes se le pre- sentan tres opciones de lectura, $\mathrm{o}$, por lo menos, así lo veo yo.

La primera opción le resultará chocante: una forma de leerlo es no leerlo. Justo en este momento se acaba de mover la tierra bajo mis pies y no se trata de un terremoto sino del alma de Aristóteles que se retuerce porque he infringido el principio de no contradicción. Pero ¿qué le vamos a hacer? Así es. Una forma de leerlo es no leerlo. Mi recomendación es que se baje algunos videos de internet y oiga las opiniones de nuestros autores en materia de libertad, derechos humanos y demás. Hay una entrevista en cuatro partes a Carlos Alberto Montaner, impagable. ¡Por Dios! ¿En qué lotería le dieron el título de periodista a la conductora del programa? Es tan malo todo que vale la pena verlo. ¿Y qué decir de las respuestas de este perseguido cubano de profesión? Pues ique viva la simpleza!

La segunda la considero totalmente desaconsejable, pero es el lector el que tiene la última palabra. Consiste en leer el libro entero. Sí, tal cual, desde el principio hasta el fin, notas a pie de página incluidas. Por las noticias que tengo esta segunda opción ha sido elegida por lectores eviternos, es decir, lectores que como usted o yo nacimos una vez pero que a diferencia de usted o yo, no morirán. Para hacérselo fácil, como los ángeles. ¿No está mal, no? Pero, claro, teniendo todo el 
tiempo del mundo no tiene mérito. Así, cualquiera.

$\mathrm{Y}$ vayamos con la tercera, la que yo elegí. Hay que comenzar por el prólogo que, como decía, lo ocupa Don Mario, el papá de Álvaro. Y ¿qué leemos? Pues que este libro resucita un estilo de rancia prosapia, es decir, de antiguo linaje. Y ¿de qué estilo se trata? Del panfleto. Panfleto: libelo difamatorio, opúsculo de carácter agresivo. ¿ $\mathrm{No}$ les resulta curioso que cuando se va a insultar a más del $75 \%$ de la humanidad se elija este estilo? Yo por lo menos hubiese escrito un grueso tratado de ontología, pero no, es el panfleto. Nos informa también Don Mario de que este estilo tuvo sus maestros en Voltaire y en Pascal. Sigamos. Una vez cubierto penosamente el prólogo, se abren las páginas al azar. ¿En qué fuentes bebe el perfecto idiota latinoamericano? La verdad es que son diversas. Van desde La historia me absolverá de Fidel Castro hasta Hacia una teología de la liberación de Gustavo Gutiérrez, pasando por La guerra de guerrillas de Ernesto "Ché" Guevara o El hombre unidimensional de Herbert Marcuse o Dependencia y desarrollo en América Latina de Cardoso y Faleto. ¿Esto es todo? No. Falta la "Biblia" del perfecto idiota. ¿Saben cuál es? Las venas abiertas de América Latina del uruguayo Eduardo Galeano, libro que recomiendo año tras año a los estudiantes. Y es que yo también estoy en la lista aunque mi nombre no aparezca.
Basta con leer alguna de las críticas que hacen nuestros iluminados a estas obras para darse cuenta que no insulta quien quiere sino quien puede, además de que se pone de manifiesto que Don Mario confunde los huevos con los mangos, porque traer a colación los nombres de Voltaire o Pascal para vendernos este engendro... Pero falta algo todavía. Si van a la parte final del libro, podrán leer frases de muchos "idiotas", incluidos nuestros cuatro "incisivos" autores. Pero, claro, tenían que autoflagelarse reconociendo su pasada idiotez y demostrando al mundo que se han curado y, si ellos lo han logrado, todos podemos hacerlo. $\mathrm{Y}$ ¿cuál es la salida? Pensar como ellos, es decir, no apuntarnos al pensamiento único, sino, como gusta decir Jesús Conill, al pensamiento hegemónico. Vayamos concluyendo ya esta introducción porque tampoco da para mucho más.

Dos son las razones que me han llevado a escribir estas líneas.

La primera es mostrar, como decía, la significancia de lo insignificante. Si algo se puede decir de este libro es que es una contribución más, si se me permite la palabra, a la des - realización de la realidad. La densa, compleja y difícil realidad humana, sea donde sea, es simplificada y recortada para poder presentarla panfletariamente. La verdad y el error nunca estuvieron tan bien definidos. A un lado los 
que saben, al otro los que ignoran. Cada día estoy más convencido de que la barbarie es la hija de la simplicidad y este manual es una muestra, de ahí su significancia. Aterra la tranquilidad con la que sus autores abordan conceptos tan escurridizos como "libertad", "derechos humanos", "teología de la liberación", "utopía"... Pero éste y no otro es el pensamiento políticamente correcto hoy, para nuestra desgracia.

Decía antes que yo en su lugar hubiese escrito un tratado de Ontología general, pero no. En vez de dar palos a diestro y siniestro como hacen nuestros sabios en su panfleto, me habría volcado en la obra de alguno de los más insignes idiotas de Latinoamérica para defender mis tesis. $Y$ ya que estamos en la UCA, ¿por qué no Ellacuría? No me digan que no encarna, que no ejemplifica al perfecto idiota $y$, además, con una producción tan extensa como variada, cualquier investigador $-\mathrm{y}$ nuestros ortodoxos lo son- puede detectar las imbecilidades que se esconden en ella. Pero, claro, esto es, si no imposible, por lo menos muy complicado. Ensayos como el de Héctor Samour, Voluntad de verdad; el de José Sols Lucía, La teología histórica de Ignacio Ellacuría; o el de Juan Antonio Senent de Frutos, Ellacuría y los derechos humanos, excelentes todos ellos, lo desaconsejan. Y es que escribir acerca de la obra del asesinado rector de la UCA lleva tiempo, muchísimo tiempo, tiempo que impide dar conferencias que se pagan... ¿Cuánto ha dicho? ¿Tanto?, recoger premios a la tolerancia o a la defensa de los derechos humanos, conceder entrevistas a la radio o a la televisión..., en resumidas cuentas, engordar la cuenta corriente. Así que lo mejor es despachar lo antes posible lo enjundioso y denso, y quedarse con lo folklórico.

La segunda razón es que nuestros escritores al parecer le han encontrado gusto a esto de insultar y al primer "varón" acaban de darle un hermanito, un mostrenco que se "Ilama" El regreso del idiota. Por las fechas en que han sido escritos los libros de Luis de Sebastián y Jon Sobrino, no creo que sean pasto de las diatribas de la "mara" de Llosa. $Y$ digo que no creo porque ni tan siquiera he visto al nuevo vástago, pero lo que sí es seguro que África, pecado de Europa y Fuera de los pobres no hay salvación aparecerán en las sucesivas obras de nuestros "liberales" como simiente intelectual del idiota latinoamericano. Así que el lector ya está advertido.

Y, ahora sí, vamos a los textos. 


\section{I. ¿Existe África?}

No he sido un seguidor atento de la obra de Luis de Sebastián, pero desde que hace ya años leí por primera vez en el diario español El país un artículo suyo, siempre que puedo le cito. Por supuesto, no recuerdo de qué iba, pero me sorprendió su tono crítico y, a mi juicio, acertado, que manifestaba. Como decía al principio, la vida te da sorpresas y quién me iba a decir que años después lo conocería justo aquí, en El Salvador.

Yo, de su vida, no sabía nada, menos de su labor importantísima en la UCA. Y fue en 2005 cuando, junto con un grupo de profesores, pude platicar con él. Nos informó de su nuevo libro, el que aquí quisiera comentar, y nos dijo que aunque estaba ya terminado no había encontrado editorial. Esto me sorprendió porque Trotta ya le había publicado otros y el nombre del autor tiene ya el suficiente prestigio. El libro era el producto de tres años de trabajo recabando y ordenando información. Luego, con gran sentido del humor, declaró que el título, África, pecado de Europa, no terminaba de convencerle porque, si no recuerdo mal, le parecía que eso de "pecado" tenía resonancias "curiles", incluso nos mencionó otros que podían sustituirlo; al final quedó el primero y yo lo encuentro acertado después de leer su contenido.
Cuenta el autor en la Introducción que tras publicar su libro Mundo rico, mundo pobre, Luis Magriñá, que estaba al frente de Intermón, le reprochó que no hubiese dicho nada de África. Luis de Sebastián le prometió que en la segunda edición eso cambiaría, pero no fue así, y África siguió sin aparecer, pero como por fortuna nuestro autor es un hombre de palabra $y$, sobre todo, de muchísimo talento, para corregir su "falta" decidió escribir un libro exclusivamente sobre ese continente que es el que tenemos en las manos.

El prólogo de Samuel Eto'o —sí, el que fuera delantero centro del Barcelona- es el arranque de un libro sorprendente, más si tenemos en cuenta el desconocimiento general que tenemos de ese continente. No sé quién dijo que Dios se había olvidado de África. En cualquier caso, uno de los nuestros, por fortuna, no y agradezcámoselo porque el esfuerzo de su autor ha valido la pena.

"Éste no es un libro más de la historia de África. Es un libro sobre las consecuencias de la presencia de Europa en África. En este libro se narran y se analizan los desaguisados que los europeos llevaron a cabo en África desde el siglo XV hasta el presente." 
Sólo por este inicio ya debería el libro ser denostado por el grupo de Vargas Llosa, pues una de las ideas más extendidas entre los idiotas latinoamericanos es que son la burguesía y el imperialismo los causantes de los males que padecemos, los males vienen siempre de fuera, repiten. Habría que recordar al grupo de Vargas Llosa, que algunos de los autores que citan son un poco más críticos, pero negar que el imperialismo y las burguesías, locales o foráneas sean, si no LA causa, una de las grandes causas, es no querer ver la realidad. Como liberales que se proclaman, debieran leer con un poco más de detenimiento el Segundo Tratado del Gobierno Civil de John Locke y así se enterarían de los principios que legitimaron el expolio allí donde los europeos Ilegaron. Obviamente, Sebastián presenta en el libro también "las cosas buenas que hicieron, junto con las que no hicieron y deberían haber hecho", vamos, que lo que nos propone el autor es una lectura matizada, no escorada y mucho menos ideologizada. Pero, claro, este libro no es un panfleto, es el brillante resultado de una larga, concienzuda y profunda investigación.

Sé por las estadísticas del Banco Mundial que el Producto Interior Bruto de todos los países africanos juntos no supone más que el $2 \%$ del PIB mundial. EI PIB conjunto del África sub-sahariana era sólo el $1.08 \%$ del PIB mundial en 2004. Es decir, si toda África se hundiera en el mar (cosa que Dios no quiera), la economía mundial sufriría una pérdida, como máximo, de un 2\% de su producto total. Es como si hubiese habido unas extensas inundaciones en Estados Unidos, o un terremoto fuerte en Japón. Nada más. La insignificancia económica de África a escala mundial es el resultado del expolio, el desgaste, el abandono y la marginación a que ha estado sometido este continente a través de los siglos.

Los datos son demoledores pero a la hora de encontrar otras causas, y no por cierto foráneas, Sebastián señala sin ningún titubeo a los gobiernos que han "regido" los destinos de esos países después de su independencia, porque si bien es cierto que son producto de la herencia colonial, son responsables de la corrupción, de las guerras tribales reinantes en el continente africano.

Seguimos todavía en la introducción y Luis de Sebastián nos arroja de entrada unos datos más para vergüenza de los que aún la tengan.

África es el continente más pobre del mundo y la mayoría de sus 600 millones de habitantes no tienen posibilidades de beneficiarse de la globalización. Las estadísticas son escandalosas:

- 300 millones de personas viven con menos de un euro diario, según el Banco Mundial 
- Más de 30 millones de personas están contagiadas de SIDA

- El 40\% de los niños no recibe educación primaria

- Unos 100 millones de personas están afectadas por las consecuencias de los conflicto armados.

Concluye la introducción con la propuesta de un paquete urgente de medidas que en el capítulo 10 se desarrollan y concretan: La debida reparación europea.

Después de narrar en el primer capítulo el encuentro entre europeos y africanos, Sebastián aborda en el segundo uno de los capítulos más repugnantes y vergonzosos de la Historia del ser humano en la tierra: La peste blanca: el comercio de esclavos:

Lo primero que hay que hacer es negar la esencia de la persona del esclavo, la cual pudiera ser la base para sustentar derechos y reclamar el respeto de otros seres humanos. Según la mentalidad de los esclavistas, además de ser paganos, adoradores de ídolos y dioses falsos, supersticiosos, y por tanto carentes de la entidad moral que da el cristianismo, eran ignorantes, medio hombres, "que no se preocupaban de nada más que de librarse de ser capturados", en frase de Newton. Interpretando la Biblia de una manera muy abusiva, los negreros veían en los africanos a los descendientes de la raza de
Cam, maldecido por Noé, quien habría legado a sus descendientes la pérdida de derechos que implicaba la maldición paterna.

El tal Newton que aparece no es el físico sino John Newton, un tipo que pasó de dedicarse al comercio de esclavos a escribir contra este ignominioso negocio. En cuanto a la legitimación de esta práctica inefable por ser descendientes de Cam, lo menos que se puedes decir es que es muy imaginativa.

Cuenta la Biblia, para ser más precisos el Génesis, que tras el diluvio, tres fueron los hijos de Noé que abandonaron el arca: Sem, Cam y Jafet. Restablecida la calma, Noé plantó una viña, bebió del vino y se embriagó. Cam, padre de Canaán, vio la desnudez de su padre y avisó a sus dos hermanos que tomaron un manto y caminando hacia atrás cubrieron el cuerpo de su padre. Al despertar éste de su sueño dijo: ¡Maldito sea Canaán! ¡Siervo de siervos sea para sus hermanos! Podían haber acudido a Aristóteles: "Hay hombres que son esclavos por naturaleza", tal y como escribe en el primer libro de la "Política", pero a esta afirmación le faltaba la sanción divina, y es que, como nos advierte Luis de Sebastián, el tráfico de esclavos se llevó a cabo en su mayor parte por cristianos.

La aceptación de la esclavitud por parte de los cristianos se basa en el concepto maniqueo, que está 
tan presente en todas las religiones, de que los paganos, o no creyentes, no tienen derechos, mientras que los religiosos, los creyentes, los tienen todos. Los creyentes, sin embargo, son los instrumentos providenciales para la salvación de los infieles, por eso en aras de su salvación, se les puede hacer la guerra, conquistar, expoliar, esclavizar, vender y comprar, con tal de que se tomen las medidas oportunas para convertirlos a la nueva religión y así salven sus almas, aunque sea sobre la ruina de sus cuerpos.

Creo que aquí se queda corto nuestro autor porque ese concepto maniqueo no sólo está en las religiones sino en todas las culturas. ¿Cuántas veces repite Walter Benjamin que todo documento de cultura es también de barbarie? ¿No dice el ilustrado Montesquieu que "hay que reconocer que la esclavitud va contra la naturaleza, aunque en ciertos países está fundada en razón natural"? ¿Cuántos son los defensores de la democracia que no han terminado proponiendo la monarquía despótica para estos pueblos?

$\mathrm{Y}$ para que esto no quede en una simple confrontación entre blancos y negros, Luis de Sebastián precisa algo que todos sabemos pero que conviene recordar: que los mismos negros se encargaban de cazar a otros para venderlos a los comerciantes a cambio de los bienes que éstos les ofrecían. En la tabla siguiente se presenta el número de esclavos que desembarcaron en las costas atlánticas. Las cifras anonadan.

\begin{tabular}{|l|r|}
\hline $1450-1600$ & 367.000 \\
\hline $1601-1700$ & 1.868 .000 \\
\hline $1701-1800$ & 6.133 .000 \\
\hline $1801-1900$ & 3.330 .000 \\
\hline TOTAL & $\mathbf{1 1 . 6 9 8 . 0 0 0}$ \\
\hline
\end{tabular}

Si esto se hizo con los habitantes del continente africano, no es difícil adivinar la suerte que corrieron sus tierras. La Conferencia sobre África occidental tuvo lugar en Berlín entre 1884 y 1885 sin la presencia, por supuesto, de ningún representante africano. Las potencias occidentales se sentaron ante un mapa para repartirse el dominio de un continente ajeno. Creo que esta escena - con todas las diferencias desde luego- aún podemos revivirla si presenciamos aquella otra que nos muestra Francis Ford Coppola en su excelente segunda parte de El padrino.

En la azotea del Hotel Nacional de La Habana, aprovechando el cumpleaños de Hyman Roth, un grupo de mafiosos se reparte la isla simbolizada en la tarta de cumpleaños que Johnny Ola, lugarteniente de aquél, se apresta a trocear. Por cierto, se trataba de la Cuba de 
Fulgencio Batista y no la de Fidel Castro, así que el Mal aún no se había hecho presente en el mundo. Sin embargo hay un matiz que considero importante. Mientras que los mafiosos no necesitaban legitimar sus turbias acciones en la isla, se trataba de simples negocios, los europeos que se repartieron África tuvieron que salvar su civilizada conciencia esgrimiendo razones tan peregrinas, el caso de Newton, y tan poco originales como que el continente estaba vacío, que aqueIlas gentes eran incapaces de organizarse, que la divina providencia quería que aquellos bienes fuesen compartidos por todos los demás pueblos de la tierra... Por todos, como bien matiza Luis de Sebastián, se entiende los pueblos de Europa en primer lugar. En resumen, estamos ante un calco de lo que hicieron los españoles en América. Si el lector quiere más información, le remito al excelente libro de Bartolomé Clavero titulado Derecho indígena y cultura constitucional en América.

Evidentemente, de todo esto, los europeos obtuvieron un triple beneficio: colocaron algunos de sus productos en África, obtuvieron materias primas, y explotaron a conciencia la mano de obra autóctona. ¿No les suena muy actual todo esto? Y aquí va una reflexión de Luis de Sebastián que le hace merecedor de estar en las nuevas entregas del "perfecto idiota latinoamericano".
El imperialismo económico de corte tradicional (popularizado como interpretación marxista), aunque no explica todos los episodios de la enmarañada expansión europea en África, no se puede negar que explica el impulso inicial de todo proyecto.

Sin embargo, sorpresa, sorpresa.

Es una injusticia histórica que Leopoldo II, el rey de los belgas, que murió en 1909, no figure con Hitler y Stalin, como uno de los criminales políticos más sanguinarios del siglo XX. Porque lo que hizo en África, durante los veintiún años que duró el Ilamado Estado Libre del Congo (1885-1906) fraguado por él, equivale, en salvajismo genocida e inhumanidad, a los horrores del Holocausto y del gulag.

Aunque no se lo crean, es Don Mario Vargas Llosa el autor de estas líneas. ¿En qué quedamos entonces? ¿Vale o no vale el fenómeno imperialista para comprender lo que le pasa al tercer mundo? $\mathrm{Y}$ repárese de nuevo en el matiz de da Luis de Sebastián, aunque no explica todos los episodios... Pero sigamos aunque volveremos.

Los capítulos IV y $\mathrm{V}$ están dedicados a la invasión, a la ocupación, a la resistencia y a la represión. Una vez legitimada la presencia en el continente africano lo demás era simplemente cuestión de tiempo. ¡Qué bien documentados están 
estos capítulos! Y sobre todo, ¡qué bien distribuidos! Es el turno de los exploradores, colonos, geógrafos, misioneros, etc... Y obviamente de los militares. Las luchas por las materias primas y su consiguiente explotación van dando forma a este desdichado continente cuya riqueza ha sido la fuente de sus males. Aún recuerdo al poblador de Sierra Leona en Blood diamond exclamar: ¡Que no descubran petróleo!

En el capítulo VI, el autor nos muestra al sistema colonial en pleno funcionamiento así como las estructuras sociales que lo hacían posible.

"Las únicas inversiones que se hicieron en las colonias fueron las de empresas privadas para explotar minas, plantaciones, petróleo, así como las inversiones de los colonos europeos para mejorar sus tierras y el embarque de sus cosechas."

En Ser como ellos, Eduardo Galeano con en ese leguaje tan sutil como penetrante, escribe un suelto que no me resisto a transcribir porque resume sin disimulos lo que fue el sistema —quizá sea mejor para nuestra desgracia decir que aún lo es- colonial. Se titula El mundo como plato.

La amnesia no es el triste privilegio de los países pobres. Los países ricos también aprenden a ignorar. La historia oficial no les cuenta, entre muchas cosas que no les cuenta, el origen de su riqueza. Esa riqueza, que no es inocente, proviene en gran medida de la pobreza ajena, y de ella se alimenta más y más. Impunemente, sin que le duela la conciencia ni le arda la memoria, Europa puede confirmar, cada día que la Tierra no es redonda. Razón tenían los antepasados: el mundo es un plato, y más allá se abre el abismo. Al fondo de ese abismo yace América Latina, y todo el resto del Tercer Mundo.

Creo que una vez aquí, se pone de manifiesto la incapacidad de la ciencia económica para explicar la realidad exclusivamente desde sus categorías, tal y como pretenden los liberales. La economía, como cualquier otra ciencia, dispone de autonomía, por supuesto, y de su propio campo de conocimiento, desde luego, lo malo es que al trastocar la autonomía por independencia se desgaja de la vida y termina por empobrecerla. Veámoslo.

Lo primero que salta a la vista es la imposibilidad de explicar las relaciones comerciales entre los países sólo desde la teoría de los costes comparativos de Ricardo. La teoría ricardiana, ejemplar por lo demás, deja en el tintero un concepto, tal vez porque lo presupone, esencial: la soberanía. Cuando el banquero inglés analiza las relaciones comerciales entre Portugal, país productor de vino, e Inglaterra, país productor de paño, omite que ese intercambio obedece a las decisiones de 
dos países soberanos, de ahí que el intercambio sea beneficioso para ambos. Sin embargo, en el caso africano, no es así.

Un país primermundista decide por el país colonizado y le impone una estructura económica que sólo beneficia a aquél, recuérdese lo que se mencionaba anteriormente de las inversiones extranjeras. Esta asimetría es la causa de que las relaciones reales de intercambio sean cada vez más desiguales, es decir, que los países colonizados deban exportar más para poder importar lo mismo. $\mathrm{Y}$ estas relaciones son para nuestra desgracia una realidad con la que tenemos que contar hoy mismo, de ahí las protestas contra los TLC — protestas que son tildadas por los amantes de la Libertad como absurdas e incomprensibles. De ahí que cuando se acusa al imperialismo extranjero de ser una causa importante de la pobreza y de la miseria de los países del tercer mundo no se está cayendo en la idiotez sino que se está argumentando de forma clara, contundente y comprobable.

Pero además se pone de manifiesto el sesgo ideológico que se esconde tras teorías aparentemente científicas. La obra de Rostov, Las etapas del crecimiento económico, sigue siendo hoy la Biblia para una corriente de economistas que ve en el desarrollo económico un premio a la eficacia y eficiencia, y en el subdesarrollo, el castigo por la ineptitud. Todos lo pueblos fueron pobres en sus inicios, entonces zpor qué unos han prosperado y otros siguen igual o peor? Apresurémosnos a decir que dicha corriente es anglosajona o si se quiere primermundista, de ahí que la causa sea un conjunto de virtudes presente en estos países y ausente en los demás: diligencia, rectitud, sentido del ahorro, laboriosidad, transparencia, responsabilidad, etc.. Claro, en el otro lado, el asunto se ve muy diferente y se puede resumir en una frase del periodista español ya fallecido, Manuel Vázquez Montalban: Hay países subdesarrollados porque hay países subdesarrollantes, algo que se acerca más a la realidad aquí presentada.

Dicho de una forma más académica, tenemos recordar una teoría que no nació en el primer mundo sino en el otro, para dar cuenta del abismo cada vez mayor que se abría entre el Norte y el Sur —que también existe, como nos recordaba el poeta uruguayo Benedetti-: la teoría del "centro-periferia", defendida por los economistas de la CEPAL, entre otros. El centro manda, la periferia obedece. La periferia producirá básicamente lo que el centro demande más allá de las necesidades de las poblaciones de aquélla. El resultado no puede ser sino calamitoso para unos y muy exitoso para otros, unas economías cada vez más débiles y dependientes por un lado, y otras, cada vez mejor abastecidas y, además, a bajo 
coste. El negocio es simplemente redondo.

¿Qué factor permite que esto siga aún funcionando? Obviamente la violencia. ¿Qué pretenden, si no, esas asociaciones e instituciones que quieren promover el comercio justo, sino acabar con prácticas que insultan a la dignidad del trabajador y que arruinan a la tierra?

Como todo el mundo sabe, la vida humana no consta sólo de economía. Pero esto debería tenerse siempre en cuenta también en la práctica: la economía de mercado no es un fin en sí misma, sino que debe hallarse al servicio de las necesidades del hombre en vez de someter implacablemente a los seres humanos a la lógica del mercado. (...) Dicho desde el punto de vista sociológico, la economía y, por tanto, el mercado, es sólo un subsistema de la sociedad, con el que coexisten otros subsistemas como el derecho, la política, la ciencia, la cultura y la religión. (...) Pero en el ultraliberalismo economicista existe el peligro de que el subsistema de economía de mercado se eleve de hecho a la categoría de un sistema total, de modo que derecho, política, ciencia, cultura y religión no sólo sean analizados mediante instrumentos económicos (lo que sería legítimo), sino que se vean en la práctica sometidos a la economía y domesticados por ella $y$, en definitiva, desvirtuados.
La claridad con la se expresa Hans Küng (otro que no aparece en el manual, pero aparecerá, seguro) evita cualquier comentario.

Pero, claro, estas actividades tan lucrativas no pueden Ilevarse a cabo sin los corruptos vendepatrias que habitan en la periferia, por eso es conveniente saber cómo fue la administración colonial.

Luis de Sebastián nos advierte de algo de capital importancia y que por ello no puede ni debe ser pasado por alto: la distinción entre protectorados y colonias, porque sus secuelas hoy todavía están tristemente presentes. Mientras que el protectorado era una forma de gobierno en la cual el país protegido conservaba, al menos formalmente, el poder tradicional de los jefes de la tribu, gobiernos locales y de aldea, en las colonias, el gobierno autóctono era eliminado y sustituido por un gobierno colonial. En resumen, sea como fuere la administración, lo que está claro es que los países invadidos — creo que es el término justo y correcto- no sólo perdían automáticamente la soberanía sino que veían emerger una sociedad dual, y esto es lo grave, porque aquí encontramos la explicación de las limpiezas étnicas que aún hoy perduran por desgracia. 
Luis de Sebastián tiene la palabra:

El régimen colonial tuvo un efecto sobre la sociedad africana parecido al que había tenido siglos antes del tráfico de esclavos: creó unas élites nativas, separadas del grueso de la población, que supieron sacar partido de la ocupación colonial. (...) En la medida que el régimen colonial creó estas élites y las separó de las mayorías pobres del país, en esa medida contribuyó a construir una sociedad dual que ha perdurado, más allá de la independencia, hasta nuestros días.

Y saltando unas páginas,

Por sociedades duales entendemos sociedades con unas pequeñas élites, europeizantes o europeizadas, educadas, ricas, armadas, organizadas, conectadas con las empresas mineras, petroleras, madereras o fruteras que trabajan en el país, con vínculos en el exterior. En definitiva, élites que se encuentran en una situación de absoluto privilegio. África es un continente de élites, donde en cada nueva nación hay una minoría de ciudadanos, un 1 ó $2 \%$ de la población, que disfrutan de las mismas posibilidades y recursos que las personas más ricas de otros continentes.

Frente a este grupo, el $75 \%$ de la población vive en la más completa marginación e indefensión ante el poder arbitrario de los elegidos.

Pero, con todo esto, la faena quedaría incompleta porque falta lo fundamental, es decir, una nueva legitimación y, ahora más que nun- ca, son muy ilustrativas las palabras de Ellacuría que recordábamos al inicio: ¿el descubrimiento?, no, la invención. El "descubridor" no descubre nada porque su propio papel se lo impide. Luis de Sebastián trae a colación unas líneas de J. Reader muy ilustrativas.

Dado que se suponía que África no tenía historia antes de la llegada de los europeos, no sería exagerado decir que Europa creó la imagen de África que la época colonial transmitió al mundo. Una vez que hubo trazado el mapa de los Estados - nación y emprendido el establecimiento de un gobierno civilizador en cada uno de ellos, con una administración jerárquica y apoyo militar, África y la vida de sus habitantes fueron reestructuradas para adaptarlas a la idea europea de cómo tenían que ser.

Es lo de siempre. Fíjense qué similar es esto a lo que escribe Edmundo $\mathrm{O}^{\prime}$ Gorman en su ensayo $\mathrm{La}$ invención de América. 
Europa, pues, sede de la cultura y asiento de la Cristiandad, asumía la representación del destino inmanente y transcendente de la humanidad, y la historia europea era el único devenir humano preñado de auténtica significación. En suma, Europa asume la Historia Universal, y los valores y las creencias de la civilización europea se ofrecen como el paradigma histórico y norma suprema para enjuiciar y valorar las demás civilizaciones.

Los siguientes capítulos "Europa abandona África", "El África que dejaron los europeos", "Las diez plagas que azotan África" y "La debida reparación europea" son una demostración de la paciente, laboriosa, brillante y sosegada investigación del autor.

Realmente no se puede pedir más. Pero de todo ello permítanme extraer un fragmento que considero crucial para entender el presente de África. Películas como Hotel Rwanda, Diamante de sangre, Lágrimas del sol y otras, han mostrado en sus imágenes un grado de violencia y barbarie que cuando menos nos han estremecido. Ver a niños de cortísima edad portando armas, con más odio del que cabe en sus diminutos cuerpos, disparar contra aquél que es considerado enemigo; personas — sin distinción-con los miembros amputados; violaciones en masa, etc... Espeluznante en verdad, pero quizá sea bueno recordar las palabras de Walter Benjamin cuando nos espetaba lo poco filosófico que resultaba sorprenderse ante el nazismo recordándonos que el estado de excepción es el estado de normalidad de los oprimidos. Lean estas líneas.

Los europeos dejaron bien inculcada en África una lección que los africanos habían aprendido a su costa: que la fuerza de las armas es el único y definitivo recurso para la conquista del poder. Ni la fuerza de las razones, ni la convergencia de los deseos de la mayoría de los ciudadanos, ni los votos, ni las tradiciones, ni el parecer de los ancianos podían con la lógica aplastante de un aplastante poder militar. Los europeos, siendo pocos en número, conquistaron el poder sobre los pueblos nativos con la fuerza de las armas. El armamento y su potencia de fuego era el instrumento definitivo en la lucha por el poder.

¿Quieren un diamante más de barbarie y crueldad pero rebozado de franco paternalismo? Habla de las Indias Occidentales pero seguimos en África. Es un fragmento que Edward W. Said en su ensayo Cultura e imperialismo extrae de la obra de Carlyle, The nigger question:

"No: los dioses desean que, además de las calabazas (vegetal preferido por los "negros" de Carlyle), en sus Indias Occidentales crezcan especias y otros productos exquisitos; esto han declarado ellos al crear las Indias Occidentales; 
pero desean mucho más, desean que hombres industriosos ocupen sus Indias Occidentales, iy no ese ganado bípedo por más "feliz" que se muestre con sus abundantes calabazas! Hemos de saber que los dioses inmortales han decidido ambas cosas y han sancionado para ambas su eterna acta del Parlamento: y ambas, contra todos los parlamentos y entidades terrestres, se llevarán a cabo. Si Quashee no ayuda a recolectar especias se convertirá nuevamente en esclavo (estado que será apenas menos desagradable que el actual) y con benéfico látigo, si los otros métodos no lo consiguen, se le obligará a trabajar."

Si el lector ha llegado hasta aquí habrá comprobado que África, pecado de Europa es un ensayo imprescindible no sólo para conocer a ese gran desconocido continente sino para saber algo más de lo que nos pasa también en el Nuevo Mundo.

Luis de Sebastián pasó muchos años en El Salvador, años además terribles, y eso se percibe en la forma de abordar los problemas con los que se enfrenta el Ilamado eufemísticamente Tercer Mundo. Lo decía y lo repito, denunciar el expolio sufrido por estos continentes no es caer como dicen los "conspicuos" y "sobresalientes" autores del Manual del perfecto idiota latinoamericano en el típico y manido tópico: la culpa la tienen los de fuera, es reconocer lo que no se puede olvidar ni borrar. ¿Por qué dedica si no nuestro autor todo un capítulo a la reparación debida? El Tercer Mundo es un temible espejo en el que el Primero no quiere mirarse porque se asusta ante lo que ve. Desde los albores de la llamada cultura occidental se repite aquello que Benjamin vio como nadie, que todo documento de cultura es también de barbarie. La Grecia Clásica no se entiende sin la esclavitud, del mismo modo que no se entiende la Ilustración - y aquí estoy en total sintonía con Dussel - sin el cruel latrocinio- ipuede ser de otra forma? - de los europeos en los mundos "descubiertos". Y todo esto puede verse bien reflejado en las apasionantes líneas de la obra. Pero, claro, estamos ante un intelectual que utiliza la economía para saltar más allá, es decir, estamos ante un economista que no teme reconocer que la ética, la política, están antes que la economía, lo que para muchos resulta incomprensible.

Ya habrán notado que no me he esmerado mucho en las citas, sin embargo haré una excepción. En una obra anterior de nuestro autor Un mundo por hacer. Claves para comprender la globalización, Trotta, en la página 53, escribe

Afirmo que la desigualdad económica a la que me refiero es mala, porque pone en peligro a la democracia, (...) y porque es ineficiente e implica un mal uso de los recursos. 


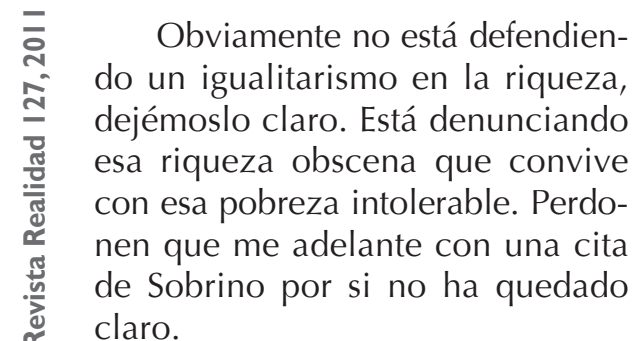

"En un mundo de pobreza la ostentación de la abundancia y el silencio ante la miseria deshumanizan. Y más deshumaniza la simultaneidad de ambas cosas."

Pero si desde el punto de vista ético algunos no lo tienen claro, Luis de Sebastián pasa a argumentos estrictamente económicos y razona así en la página 54:

"La desigualdad económica es además ineficiente, porque conlleva un reparto de la riqueza que no maximiza la utilidad marginal total del dinero (que se toma aquí como la forma tipo de riqueza) de la sociedad. La utilidad marginal de los últimos 1.000 dólares que recibe uno de esos 400 billonarios es muchísimo menor que la utilidad de los mil dólares marginales que recibe cada uno de los 30 millones de pobres. Si se quitaran - por las buenas, naturalmente30.000 de dólares a los 400 más ricos y se repartiera a razón de 1.000 dólares por persona entre los 30 millones de pobres, la utilidad marginal total del dinero aumentaría significativamente. En otras palabras, repartiendo mejor el dinero se puede conseguir una suma mayor de satisfacción o bienestar en la sociedad.

No sé si les parece racional y razonable el argumento, en cualquier caso es el que se ha esgrimido para defender el impuesto directo y progresivo sobre la renta. El problema es que no tiene predicamento en una economía que no diferencia entre necesidades y deseos. Aristóteles hizo la distinción y concluía que de no tenerla en cuenta la codicia sería irrefrenable lo que imposibilitaría el orden social. Pero, perdón, ¿a quién le interesa la sociedad? Les recuerdo que el instigador de la nueva economía, Friedrich von Hayek, ya fallecido, publicó hace años un artículo titulado El atavismo de la justicia social a él le remito al lector y que saque sus propias conclusiones.

Luis de Sebastián aborda la cuestión de la utilidad marginal de la renta como si ésta presentase al comienzo una pendiente positiva, creciente, para después dar paso a un tramo horizontal permanente. El individuo es tan rico que incrementos posteriores de renta no suponen prácticamente nada para su bienestar, de ahí que nuestro autor proponga otro tipo de distribución 
más eficiente. Craso error porque en un mundo como el nuestro la sociedad es posterior al individuo y las cosas funcionan de otra manera. La utilidad marginal de la renta, tal y como apunta Charles Dyke en su ensayo Filosofía de la economía no presenta esa figura, sino otra bien diferente.

La utilidad marginal del dinero no cambia sin altibajos. Hay algunas cosas que requieren una cantidad sustancial de dinero en bloque. Hasta que tenemos todo el bloque el cambio en la utilidad del dinero es gradual, pero una vez que lo tenemos la utilidad del dinero crece muchísimo.
Es decir que la utilidad marginal del dinero sería creciente pero de forma escalonada lo que corroboraría lo antes apuntado: nuestras necesidades son limitadas en cantidad pero cualitativamente ilimitadas, no hay tope. Ninguno de sus 400 billonarios va a aceptar sin más entregar la suma que él dice porque esos 1.000 dólares en principio no son mucho, pero son los primeros de una serie de ingresos que le van a permitir a su receptor atisbar otra nueva cima de bienestar. Si el individuo es insaciable y el derecho de propiedad es absoluto, la sociedad es imposible. Y si esto es así, tendremos que hablar de barbarie.

\section{Como atinadamente observa Sobrino:}

Esta civilización, en lo fundamental está basada en y ofrece un espíritu que en definitiva lleva a la deshumanización. Es la civilización del individuo, del éxito, del egoísta buen vivir. Y el aire que respira el espíritu se enrarece todavía más cuando el Occidente que la produce se comprende así mismo no sólo como logro de talento y nobles esfuerzos - en parte muy reales, a los cuales se añade también una secular y gigantesca depredación histórica-, sino como fruto de una predestinación, como antaño se comprendían los pueblos elegidos según las religiones.

Es, en resumen, el conflicto de dos cosmovisiones: una intentaría armonizar la razón pública con la privada, ésta es la que defiende Luis de Sebastián y que comparto; la otra subordinaría la razón pública a la privada, es la de nuestro mundo actual.
Otra joya del Premio Nobel de Economía nos la aporta Franz Hinkelammert, quien la descubre en una entrevista que el economista austriaco concedió al diario Mercurio: 
Una sociedad libre requiere de ciertas morales que en última instancia se reducen al mantenimiento de vidas: no al mantenimiento de todas las vidas porque podría ser necesario sacrificar vidas individuales para preservar un número mayor de otras vidas. Por lo tanto, las únicas reglas morales son las que llevan al "cálculo de vidas": la propiedad y el contrato.

Supongo que ésta es la regla a seguir en una sociedad eficaz y eficiente según Hayek.

"Estos seres humanos siguen siendo el desecho de la humanidad. Son millones de personas que sobran en nuestro mundo. Nadie sabe qué hacer con ellos, y son conscientes de que no cuentan para nadie. Llevan pegada a su piel toda una historia de sufrimiento, humillación, terror, hambre y muerte. Están he- ridos en su dignidad (...) Pero este trabajo con los refugiados de los Grandes Lagos es también una invitación a confiar en el ser humano, en su capacidad de superarse en las peores condiciones."

Son palabras de Teresa Florensa sacadas del libro de Jon Sobrino Fuera de los pobres no hay salvación al que le dedicaré las siguientes líneas. Así, de la ciencia social nos trasladamos a la teología.

\section{Jon Sobrino o el regreso al origen}

Para quienes como yo no estén familiarizados con el mundo de la teología, el libro de Jon Sobrino resultará cuando menos chocante empezando por el lenguaje que utiliza el autor. Es un lenguaje que hoy tacharíamos de políticamente incorrecto y Sobrino lo sabe, pero no por eso lo disfraza, al contrario, lo resalta, está en su derecho y, además, hace bien.

El título del libro es el del capítulo tercero: "Extra pauperes nulla salus" ("Fuera de los pobres no hay salvación"). Es novedoso, escandaloso y ciertamente contracultural. El lector juzgará cuán racional, o razonable, es nuestra afirmación. Personalmente, al escribir sobre el tema, siempre me asalta la perplejidad y el desasosiego. Pero me queda la esperanza de que otros criticarán, mejorarán y completarán. En cualquier caso, mantengo el título como sacudida a tomar absolutamente en serio la postración de nuestro mundo, y lo que en el debajo de la historia, tantas veces ignorado, incomprendido y despreciado, hay de salvación.

El párrafo siguiente tampoco tiene desperdicio: 
Hemos reflexionado desde la teología y desde datos y análisis a nuestro alcance sobre el mundo actual, también desde la experiencia y desde la fe. En su conjunto, sobre todo por lo que toca al "extra pauperes" la reflexión nos parece que es más mistagógica que autónomamente analítica. También es teología negativa para expresar lo que nos sobrepasa. Y pienso que para comprender - o criticar - mucho ayudará el "esprit de finesse" que recomienda Pascal.

Pues habrá que tener en cuenta la recomendación pascaliana.

El libro está dedicado al obispo Pedro Casaldáliga, algo que no debe sorprender a quien alguna vez haya oído al citado obispo porque si bien es cierto que no tiene un chorro de voz, dice las cosas con una nitidez que conmueve. $Y$ es que las cosas se pueden decir más alto, pero no más claro. Vamos, que también utiliza un lenguaje políticamente incorrecto, para que nos entendamos.

El primer artículo lleva por título: El pueblo crucificado y la civilización de la pobreza (EI "hacerse cargo de la realidad" de Ignacio Ellacuría). Basta con leer el prólogo y este título para darse cuenta de lo infundadas que son muchas de las críticas que se dirigen contra la obra de Sobrino y - por qué, nocontra la teología de la liberación.

\section{¿...? ¡Ese hijo de puta marxista} que viste sotana! Los que nos educamos en el nacional-catolicismo (¡qué preciso es este neologismo de Aranguren!), escuchamos muchas veces esta lindeza dirigida contra aquellos sacerdotes —ponga el lector en los puntos suspensivos un nombre- que no eran de la cuerda. Eran voces disonantes que no acallaban las conciencias, que no las adormecían, sino que las despertaban y las estimulaban. Pero volvamos a esta lindeza que, por ahora, no he escuchado en El Salvador.

Lo primero es un insulto, no un argumento, así que no tiene mayor importancia para el caso. Además, no insulta quien quiere sino quien puede.

Lo de marxista tiene más enjundia. Ignoro si alguna vez Jon Sobrino fue marxista o no, lo que sí creo es que hoy no lo es y además no puede serlo, ni él ni ninguno de los de su círculo. Las mentes estrechas y simples concluirán entonces: es antimarxista. Tampoco. $Y$ no lo es porque el marxismo se presente como materialismo o como ateísmo frente a lo que sería la espiritualidad religiosa, el asunto tiene más sustancia. Jon Sobrino, si realmente quiere escribir una teología desde la realidad, en este caso desde Latinoamérica, tiene la obligación intelectual, incluso moral, de conocer 
las teorías críticas de la sociedad - y el marxismo es eso- para extraer de ellas aquellos conceptos y categorías que le permitan conocer la realidad con mayor profundidad para después hacerse cargo de ella. Luego vendrá la interpretación teológica que será acertada o no.

\section{Como escribe P. Berryman,}

El marxismo no necesita ser una ideología dogmática de respuestaspara-las-preguntas. Puede servir heurísticamente para hacer más agudas esas preguntas.

Sobrino no habla de clases, habla de pobres, habla de lo que el marxismo precisamente excluyó con el término lumpemproletariado. Se dirige al marero, a la prostituta, al ladrón, a todos los que quedan en los márgenes, a los invisibles, esto es, a los que nadie nunca quiso ver. El marxismo es sólo una teoría - interesantísima y que goza de buena salud, por cierto - pero muy incompleta para dar cuenta de la vida cotidiana de los millones de personas que pueblan eso que se llama el Tercer Mundo. Atiéndase a lo que escribe Sobrino: También es teología negativa para expresar lo que nos sobrepasa. Aquí no hay una victoria final del proletariado, no hay una historia predeterminada como creyeron algunos marxista dogmáticos, aquí hay un mensaje liberador, y liberador para todos, porque mientras haya un esclavo, todos lo somos. Oía días atrás unas palabras a un actor argentino que no me resisto a repetir: Camino diez pasos y ella se aleja otros diez. Camino cien pasos y ella se aleja otros cien. ¿Para qué sirve la utopía entonces? ¡Para caminar!

Habla también de una reflexión mistagógica. El diccionario nos aclara que un discurso o escrito es mistagógico cuando presenta una verdad oculta o maravillosa, y creo que es el segundo tipo de verdad el que cuenta en este caso. Por eso, Sobrino recalca que

Es una pequeña muestra, si se quiere de cómo hacer "teología desde testigos" que no hace superflua, por supuesto, la "teología de textos", pero la enriquece y profundiza.

Si no es marxista al uso, siempre cabe encontrar otro sentido a aquello de marxistas con sotana: se meten en política. ¡Qué curioso! Hoy que le va tan mal a la iglesia española, no sólo se mete en política sino que organiza manifestaciones contra el gobierno. La vida te da sorpresas, sorpresas te da la vida... Pero avancemos algo más.

Por suerte o desgracia, como decía, me eduqué en la cultura nacional-católica y me repitieron ad nauseam que los cristianos no se metían en política. Ciertamente nunca llegué a entender a qué se referían. Quizá la interpretación más simple fuera que no había que 
tomar partido, y valga la redundancia, por ningún partido. Pero ¿Cómo hacerlo si todos estaban prohibidos? La respuesta estaba en la santa misa. No fallaba. En todas, los mismos que recomendaban la apoliticidad, pedían, pedían y volvían a pedir al Señor por el régimen de Franco y, además, sin ningún sonrojo. La respuesta como se ve era inmediata: ser cristiano era apoyar sin ningún género de dudas al poder establecido siempre que fuera de los nuestros. Punto. En esto consistía ser apolítico.

Pero ¿cómo se puede ser apolítico? Aristóteles dice que sólo los animales y los dioses quedan fuera de la "polis", ¿qué somos nosotros? El contenido de "polis" va más allá de un sistema de partidos, apunta a lo social, a la sociedad, y ¿cómo no vamos a preocuparnos por ella si en ella vivimos? Sólo por estar en ella ya estamos comprometidos y una forma de estarlo es afirmando que no lo estamos. Desconozco su experiencia, pero en mi caso, siempre que me he encontrado con un apolítico al uso he descubierto a alguien que santifica los hechos y no le va del todo mal en la vida. Déle la oportunidad de votar y siempre elige la opción más conservadora entre las conservadoras, así son de previsibles.

La solución no puede estar en salirse de este mundo y hacer frente a él un signo de protesta profético, sino en introducirse en él para reno- varlo y transformarlo hacia la utopía de la tierra nueva.

¡Cuánto irritan a las biempensantes mentes exabruptos como éste!

Es posible que el lector crea que me erijo en defensor de alguien o de algo. Se equivoca. No soy abogado, nadie me lo ha pedido $y$, además, como ya he dicho, no tengo conocimientos de teología para hacerlo. Lo único que me mueve es de nuevo mi indignación contra tanta simplificación. Recién muerto Juan Pablo II hubo un debate en TVE. Nada más acercarse al micrófono un sacerdote joven se apresuraba a confirmar lo que todo el mundo ya sabía: la teología de la liberación había nacido muerta y en ésas estábamos. Pues, la verdad, menos mal que nació muerta, porque si llega a vivir... Juan José Tamayo, uno de los teólogos mas reputados en España, trató de poner un poco de cordura en aquel debate aunque, como ya había tenido sus más y sus menos con Roma, no pudo desahogarse.

Ortega decía refiriéndose a los movimientos artísticos que éstos mueren no por la escasez sino por la sobreabundancia, y creo que esto puede ser aplicable a la teología. Se refería a que los movimientos o escuelas comienzan afirmándose en principios claros, de fácil comprensión. Con el paso del tiempo, poco a poco los seguidores los van 
recargando y recargando hasta el extremo de que tiempo después, resultan irreconocibles. Entonces o bien se asiste a su defunción o bien se vuelve a las fuentes que les dieron vida. Nunca un origen es igual a otro, pero se puede salvar el espíritu que los inspiró.

El libro de Sobrino es a mi juicio el esfuerzo de un creyente que reivindica el origen que no es otro que el Evangelio, leído, claro está, desde una realidad insoportable para las grandes mayorías, para los pobres. Sobrino reivindica el potencial subversivo que hay en cada línea del Nuevo Testamento para mostrar lo que no se quiere ver, para denunciar lo normal que, por cierto, está muy lejos de serlo. Y, claro, esto molesta y disgusta a los biempensantes.

En la magnífica ponencia que el teólogo Juan José Tamayo escribió para el II Congreso de Zubiri, dedicado a Ellacuría, encontramos este párrafo. No tiene desperdicio.

Es necesario evitar concepciones espiritualistas o sólo trans-históricas de salvación, que implican una ideologización de la salvación. Ellacuría aplica a la salvación lo que la Primera Carta de Juan dice del amor a Dios y al prójimo: quien dice buscar la salvación meta-histórica que no se ve, y descuida la salvación histórica que se ve, es un mentiroso.

¿Era preciso esperar diecinueve siglos para que apareciera Marx teniendo a nuestra disposición El sermón de la montaña? ¿Tiene esto algo que ver con la famosa resignación cristiana es este mundo porque en el otro Dios proveerá? Y ¿cómo es posible hablar de salvación histórica sin denunciar la situación de los marginados, la mayoría en este mundo, sin denunciar los excesos de un capitalismo depredador e inhumano?

Sobrino cita a Luis de Sebastián para luego extraer una interesante $y$ matizada reflexión.

El capitalismo real es el responsable de la mala organización ético-moral de la economía mundial y de la convivencia vergonzosa, irracional y absurda en un mundo cada vez más integrado, de una indebida pobreza con una riqueza nunca vista.

Hasta aquí el economista. Ahora el teólogo:

Esto suele pasar hoy más desapercibido, y la crítica, cuando existe, versa más sobre el adjetivo: capitalismo salvaje, que sobre el capitalismo en sí mismo, y sobre el principio que lo sustenta: el derecho de propiedad. Mientras ese principio se mantenga como absoluto e intocable, la economía estaré configurada estructuralmente por un dinamismo opresor, 
el ser humano será comprendido desde su capacidad para producir riqueza, y su derecho a poseerla y disfrutarla proseguirá y aumentará la opresión, y ciertamente la distancia entre unos y otros.

Hasta aquí, Sobrino. Ésta es de Galeano:

La difusión masiva de esos modelos de consumo, si posible fuera, tiene un pequeño inconveniente: se necesitarían diez planetas como éste para que los países pobres pudieran consumir tanto como consumen los ricos, según las conclusiones del fundamentado informe Bruntland, presentado ante la Comisión Mundial de Medio Ambiente y Desarrollo en 1987.

Consideren en la primera el calificativo de absoluto porque aquí está una de los puntos de fricción cuando se habla de los derechos: ¿Tienen carácter absoluto? Si tienen carácter absoluto, cada uno de ellos es que están desligados entre sí, y entonces, ¿qué ocurre con el derecho a la vida? Kant decía que en el estado de naturaleza no hay propiedad; lo que hay es posesión, y ya sabemos que en dicho estado no hay normas ni leyes, ¿puede entonces haber derechos? El del más fuerte, pero éste no es un derecho tal y como entendemos el término. Sólo con la aparición del Estado podemos hablar de derechos, por tanto, como instituciones que son pueden ser legítimamente limitadas por Aquél si el bien público lo requiriese. Sobrino da en el blanco siguiendo casi la misma argumentación de Rawls - un liberal educado, no un marxista- en su polémica con Nozick.
Otro autor, en este caso el filósofo francés Vladimir Jankélévitch, hablando del mal, escribe algo muy similar a lo de Sobrino:

Más exactamente: el mal no radica en tal o cual regla de acción, sino, en general, en el hecho de que tal o cual regla de acción eleva sus propias exigencias independientemente de las demás; y una virtud, separada de todas las demás, es un vicio. Por eso la perversidad no suele tener contenido alguno en particular: la perversión, que hace perversa la perversidad, radica casi por entero en el rechazo a considerar el conjunto de los demás valores. Excelencias y perfecciones devienen entonces seniles, perversas y malas por efecto de la atomización; son entonces grises y secas como el polvo.

Y un dato cruel: 
Si hubiera un poco de humanidad y compasión entre los humanos, bastaría con retirar apenas un $4 \%$ de la 225 mayores fortunas del mundo para dar comida, agua, salud, educación a toda la humanidad.

(Mientras escribo estas líneas, el diario español El país nos informa de la alteración que se ha producido según Forbes en la lista de los más ricos del mundo. Omito el nombre pero no la fortuna del afortunado: 62.000 millones de dólares.)

Ante tamaña injusticia, ¿cómo reacciona el Vaticano?

En este pontificado se han batido todos los récords de beatificacio- nes y canonizaciones, pero a mi entender, ni uno sólo de los hombres y mujeres que han sido asesinados en el Tercer Mundo por practicar la justicia, defender a los pobres, ser fieles a Jesús, en definitiva, han sido reconocidos por el Vaticano. Y nada digamos de los pueblos crucificados en África, Asia y América Latina. También en el nivel eclesiástico solemne permanecen sin nombre.

Se refiere al pontificado de Juan Pablo II, pero por ahora no hay novedades tampoco en éste. Sobrino sigue en la línea de su maestro y amigo Ignacio Ellacuría en la detección de las patologías que sufren las instituciones, y la Iglesia no es inmune. Volvamos al texto de Tamayo:

Una Iglesia centrada en sí misma no es ni puede ser sacramento de salvación; es más bien un poder anti-salvador, un obstáculo para la salvación en la historia y de la historia. La Iglesia es sacramento de la salvación de Cristo cuando se vacía de símisma, deja de ser centro, se ofrece como don, se da a las personas y a los colectivos necesitados, se abre al mundo y se coloca a su servicio en la marcha de la historia.

Ahora, repárese en el concepto de pueblo crucificado porque es, valga la redundancia, crucial para la teología de la liberación. Decía que Sobrino conoce la repercusión del lenguaje que utiliza y esta categoría como poco aturde.

Se podrá decir que, a fin de cuentas, el pueblo crucificado es sólo lenguaje, pero hay que recor- dar que estamos inmersos en una batalla del lenguaje, a la cual se dedican ingentes recursos. No es lo mismo hablar de subdesarrollo, y menos de pueblos en vías de desarrollo, que de crucifixión. Lo primero se puede cooptar fácilmente. Lo segundo, no, y por eso se silencia. Quizás el lenguaje de pueblos crucificados ayude a ganar la batalla del lenguaje, y, así, la batalla alrededor de la verdad. 
Más todavía:

De ahí el lenguaje pueblo, pueblos, etc. Que está transido de muerte, y no de una muerte natural, sino de una muerte histórica que toma la forma de crucifixión, asesinato, activa privación histórica de la vida, lenta o rápidamente. A esa muerte, producto de la injusticia, acompaña la crueldad, el desprecio y, por otra parte, el encubrimiento. A esto suelo añadir que al pueblo crucificado, además se le niega la palabra y hasta el nombre, y con ello se le niega la existencia. El pueblo crucificado no es, y el mundo de la abundancia impide o dificulta que llegue a ser. Así, puede desentenderse - sin mala conciencia - de lo que ocurre a esas mayorías.

No son artilugios o adornos retóricos manidos, son metáforas que dan qué pensar, pues están preñadas de sentido y de denuncia.

Otro aspecto que el lector ya habrá descubierto es la opción por los pobres. Con el Evangelio en la mano, Sobrino nos advierte que es preciso reformular el concepto de "pobre", pues el que se veía en la Palestina del siglo I de nuestra era no coincide totalmente con el de hoy, pero persiste una constante: tanto para uno como para otro, vivir es una carga muy pesada, y en esa carga se expresa la "hondura" de la pobreza. Pero ¿quiénes son los pobres? Antes de abordar esta cuestión es preciso no pasar por alto estas ilustrativas líneas.

Pero ante la crítica de que la teología de la liberación se centró unilateralmente en el pobre económico, me parece importante recordar dos cosas. Una es el horror, ayer como hoy, de la pobreza cruel, en forma de hambre y enfermedades relacionadas con el hambre, que anualmente da muerte a cincuenta millones de personas. La otra es que lo económico, si se vuelve a su raíz, apunta al elemento de oikos de la vida humana, el vivirla no sólo en un oikos, como lugar físico, sino en vivirla como oikos, es decir, como núcleo de humanidad. En ese sentido, la pobreza económica expresa honda carencia humana, antropológica y social: la dificultad de formar hogar, vida humana, un oikos.

El texto está en total sintonía y congruencia con los anteriores. Al marxismo se le acusó injustamente de economicismo porque se decía que en la base de todo estaba la economía. Como se ve, la teología de la liberación tampoco ha podido escapar a semejantes críticas. Y como ahora ya se puede colegir, las críticas indican un profundo desco- 
nocimiento de lo criticado, porque en el caso marxista, si un sistema el económico, el político, etc. - no se puede entender al margen de los demás - no hay parte sin todo, lo abstracto y lo concreto -, en el caso de la teología de liberación es la realidad, zubirianamente entendida, el fondo irrebasable desde donde todo debe ser pensado. $\mathrm{Ni}$ en un caso ni en otro tienen cabida los simples y fáciles reduccionismos. Y esto es lo que le permite a Sobrino abordar la realidad de los pobres desde distintas dimensiones.

En primer lugar serían los materialmente pobres, los que no dan su vida por supuesta. Pobres son "los que mueren antes de tiempo". Aquí comienza y termina la economía, aunque ésta no haya dado todavía una definición precisa de "pobreza".

En segundo lugar, los dialécticamente pobres. Los excluidos del trabajo y de la sociedad. "Se les niega su ser socio, compañero". Son los inexistentes, los invisibles.

En tercer lugar, los conscientemente pobres. Conscientes de que su pobreza no es ni natural ni, sobre todo, querida por Dios.

En cuarto lugar, los liberadoramente pobres, los que transforman esa conciencia en praxis de liberación.

En quinto lugar, los espiritualmente pobres.
Entendiendo aquí la espiritualidad en sentido preciso: los que viven su materialidad, su toma de conciencia y su praxis con gratuidad, con esperanza, con misericordia, con fortaleza en la persecución, con amor y con el mayor amor de dar la vida por la liberación de las mayorías pobres (El espíritu de las bienaventuranzas con que vivir en la realidad).

Tras esto sólo puedo insistir en lo ya apuntado: ignoro la reflexión teológica que hay en los textos de Sobrino, pero de lo que estoy completamente seguro es que el punto de partida son los evangelios. Unos evangelios que no pueden, que no deben ser leídos al margen de la realidad, en este caso, la latinoamericana. Una Iglesia que quiera formar parte de la sociedad, que quiera además servirla, está obligada a conocer la realidad en la que está inserta, realidad que siendo múltiple y diversa - los problemas del Primer Mundo no son los mismos que los del Tercero- exige diferentes mensajes pero que tiene siempre un mismo destinatario: el ser humano, ese ser humano que tan bien describe Leonardo Boff en El águila y la gallina. Una metáfora de la condición humana:

Somos gallinas, seres concretos e históricos. Pero jamás debemos olvidar nuestra apertura infinita, nuestra pasión indomable, nuestro proyecto infinito: nuestra dimensión águila. 
Ay de nosotros, si pretendemos ser sólo águilas que vuelan en las alturas, que enfrentan las tempestades y tienen como horizonte el sol y el infinito del universo. Acabaremos muriendo de hambre. El águila, por más que vuele en las alturas, está obligada a bajar al suelo para alimentarse, cazar un conejo, un perezoso o cualquier otro animal. Somos águilas pero debemos reconocer nuestro arraigo en una historia concreta, en una biografía irreductible con sus limitaciones y contradicciones: nuestra dimensión gallina.

¿Será que la teología tradicional haya olvidado nuestra dimensión gallina ocupándose de falsas águilas? ¿Será lo contrario? Recuérdese que deben ir juntas las dos dimensiones, si falta una, la otra perece. ¿No será esto lo que molesta e irrita de la teología de la liberación, haber mantenido esa tensión entre ambas dimensiones? ¿Desaparece la espiritualidad por ello? Y volvemos al inicio porque si les tacha de marxistas a estos teólogos, la espiritualidad queda en entredicho.

Una acusación como lo es la carencia de espiritualidad lleva a la pregunta: ¿quién puede hacerla? ¿Hay algo así como un espiritualitómetro que le permita al inquisidor de turno medirla? ¿En qué tiempo vive una determinada Iglesia que acusa y espera a que el acusado demuestre su inocencia? ¿No es el principio de presunción de inocen- cia uno de los logros más preciados del ser humano?

Bien, supongamos que todos los teólogos de la liberación estén equivocados, ¿no sería lo más razonable dialogar y debatir las posturas de cada escuela? Pues mire, lector, esto es imposible. ¿Por qué? Lea estas líneas y lo sabrá:

¿Jurídicamente, la noción de error y herejía tienen igual significado?

El significado de la noción de error es más amplio que el de la noción de herejía, pues si toda herejía es un error, todo error no es una herejía. Y si todo hereje se equivoca, todos los que se equivocan no son necesariamente herejes.

Pero en el ámbito de la fe, herejía y error son perfectamente sinónimos.

Esta joyita pertenece a Jaume Eimeric, un dominico español, que en 1376 escribió un tratadito que Ileva por título "El manual de los inquisidores" y que por encargo de la Santa Sede fue comentado por el canonista español Francisco Peña en 1578. Cualquiera se puede imaginar que estamos ante todo un tratado por la "tolerancia", y conste que no entiendo por ésta el respeto a las ideas ajenas, sino el respeto a las personas - lo único respetable- por encima de las ideas que sustenten -éstas son las que tienen 
que hacerse respetar de forma argumentada. En cualquier debate, lo que debe de saber cada participante es que su integridad física personal no corre ningún riesgo defienda las ideas que defienda. No valen ni la excomunión, ni la reprimenda, ni la exclusión, ni mucho menos la tortura, algo que nuestro inquisidor, verdadero profesor del triste Torquemada, practicaba con fruición y deleite para horror de sus víctimas. Pero hay más diamantes:

"... de todo lo antedicho se sigue que la noción de herejía abarca los tres conceptos de elección, adhesión y división."

Ciertamente no tiene desperdicio. El hereje se condena porque elige. Para el inquisidor la elección es caprichosa, no existe una elección racional o razonable porque ¿qué puede elegir alguien al margen de la verdad que, por supuesto, pertenece por completo a aquél? "No pienses porque ya pensamos nosotros por ti". ¡Qué lejos estamos de Kant y su "atrévete a saber" o "abandona tu minoría de edad"! San Agustín nos anima a que interpretemos los textos pues hay algunos cuya oscuridad puede paralizar el entendimiento. Pero también recomienda que dicha interpretación no rompa la coherencia del texto. Es evidente que no todas las interpretaciones son correctas, pero ¿sólo hay una verdadera?
¿Qué hacer con alguien que persiste en el error? La adhesión es una confirmación de la perversidad del condenado al negarse a reconocer la "prístina" verdad que se le muestra.

Y, claro, lo único que pretende el hereje es la división y el debilitamiento de la comunidad, lo que lo convierte en un verdadero delincuente, en un terrorista intelectual.

Ya sé que es el tópico más utilizado, pero Galileo encarna perfectamente a esas víctimas de la sinrazón. Se salió del molde al afirmar la teoría copernicana frente a la aristotélica al uso. Nunca se le dio un argumento que hiciera al científico rectificar y fue excomulgado. Afortunadamente más de 350 años después la Iglesia reconoció su error y le retiró la excomunión. ¿Qué ocurre hoy con todos esos sacerdotes desprovistos de sus cátedras de Teología? Están todos bien, gracias.

Visto lo anterior, podemos preguntarnos cómo leen los teólogos de la liberación los textos sagrados, ¿tan equivocados están? Sobre este asunto merece la pena leer lo que Phillip Berryman escribe al respecto:

La teología de la liberación es muy bíblica, pero no es literal o fundamentalista. Antes de la llustración, las iglesias simplemente suponían que las Escrituras eran el resultado de un dictado directo de 
Dios a Moisés, a los evangelistas y a otros autores bíblicos. Sólo lenta y penosamente han aceptado las iglesias métodos históricos y críticos que revelaron, por ejemplo, que los supuestamente libros mosaicos eran el resultado de muchos siglos de tradición. En forma similar, los Evangelios dan acceso a Jesús sólo a través de comunidades cristianas muchas décadas después de su vida. El sermón de la montaña, por ejemplo, no es un registro palabra por palabra de Jesús, sino una colección de dichos atribuidos a él. Sólo en los últimos veinticinco años ha aceptado el catolicismo los resultados de la erudición bíblica moderna.

Y unas páginas más adelante,

Ciertamente, durante su vida la mayoría de estos teólogos han visto cambiar su propio entendimiento del cristianismo. Su fe puede ser menos literal de lo que era hace veinticinco años. Sin embargo creo que su respuesta puede ser que su experiencia con la gente pobre ha profundizado y validado su fe.

Otro ataque sin fundamento $y$ al hilo del pretendido marxismo que anida en la teología de la liberación y que encuentra eco en el Manual del perfecto idiota latinoamericano, es creer que la citada es teología es única, monolítica, conclusa $y$, por tanto, ya dispuesta a ser indoctrinada. Volvamos a Berryman:

En cualquier caso, estos teólogos, como muchos otros latinoamericanos, están convencidos de que los futuros intentos para crear un nuevo tipo de sociedad no necesitan copiar los modelos existentes, como el de Cuba, sino que pueden crear algo nuevo. Propugnan un tipo de discernimiento que llevará a una sociedad más justa con el menor grado de improbabilidad.

Particularmente suscribo todo lo anterior y creo que quien lea la obra Fuera de los pobres no hay salvación de forma no sesgada o torticera, también lo hará.

Pero no quisiera terminar estas líneas dedicadas al excelente, valiente, claro - la mejor introducción para un profano en el mundo de la teología de la liberación-y sincero libro de Jon Sobrino sin hacer alguna matización. Y ahora sí voy a citar. En la página 110, leemos:

"Crítica o sapiencialmente, la posmodernidad ha desprestigiado la utopía, ha puesto fin a los grandes relatos y aconseja, como más razonable, pactar con relatos más pequeños, lo cual para los ricos significa moderación (...), mientras que para los pobres significa resignación (...). Pero la posmodernidad debiera tener muy presente que los grandes relatos siguen campantes en nuestro mundo - eso, sí, 
desde lo negativo - en África, Asia central, América Latina en su conjunto."

Y Sobrino no es el único en pensar así. En esta misma dirección apunta también Edward W. Said al tratar el tema del papel del intelectual. La cita es un poco larga pero sin desperdicio:

El objetivo de la actividad del intelectual es hacer progresar la libertad y el conocimiento humanos. Esto sigue siendo verdad, en mi opinión, a pesar de que hoy se repita a menudo aquello de que "las grandes narrativas de emancipación e ilustración", como designa el filósofo francés contemporáneo Lyotard a tan heroicas ambiciones asociadas con la anterior edad "moderna", han dejado de tener validez en la época del posmodernismo. De acuerdo con esta forma de ver las cosas, los grandes relatos han sido sustituidos por situaciones y juegos de lenguaje locales; los intelectuales posmodernos aprecian ahora la competencia, y no los valores universales como la verdad y la libertad. Personalmente siempre he pensado que Lyotard y sus seguidores no hacen otra cosa que reconocer otra cosa que su incapacidad y pereza, y hasta tal vez su indiferencia, sin evaluar correctamente el abanico verdaderamente amplio de oportunidades que a pesar del posmodernismo están al alcance del intelectual. Si tenemos en cuenta que de hecho hay gobiernos que evidentemente oprimen a algunas personas y que siguen produciéndose serias desviaciones de la justicia, la cooptación y el confinamiento de los intelectuales por parte del poder puede ser todavía un medio eficaz para acallar sus voces, y la desviación de los intelectuales de su vocación sigue siendo de hecho un fenómeno bastante frecuente.

No es difícil llegar a estas conclusiones tras la lectura de la obra de Lyotard, pero el filósofo francés no es ni el único ni el mejor representante del pensamiento posmoderno. Ahí están también para darles la razón, esas teologías del capitalismo que estudió a conciencia el tristemente fallecido J. M. Mardones. O también aquel artículo de los 80 de Francis Fukuyama anunciando nada más ni nada menos que "El fin de la Historia" y que tantos ríos de tinta generó. El desliz que cometen, en mi opinión, los que así se expresan al hablar de la posmodernidad es creer que detrás de una bien definida época moderna que lo prometía todo y que dejó lo que hoy todos ya sabemos, viene una época de desencanto, pereza intelectual, individualismo y resignación, cuando no una gran complacencia ante la barbarie que vivimos.

Según yo lo entiendo, hoy no podemos definir la posmodernidad porque aún no sabemos qué es la modernidad. Sí, todos estamos de 
acuerdo en identificar modernidad con racionalidad, pero ¿qué racionalidad? Intentaré argumentar mi postura sin salirme de la UCA.

En 2001, el doctor Juan Antonio Nicolás de la Universidad de Granada $-y$ viejo conocido de la nuestra, en la que ha trabajado mucho y con excelencia- editó junto a su colega María J. Frapolli un libro que Ilevaba por título Evaluando la Modernidad y por subtítulo El legado cartesiano en el pensamiento actual. Esto, en principio, nada tiene de extraño porque estamos acostumbrados a ver a Descartes como el padre de la Modernidad, el nacimiento del racionalismo y del idealismo. Cuatro años después, el mismo profesor impartió en esta Universidad un interesantísimo curso sobre uno de los filósofos más desconocidos, y no por el nombre, sino por su obra, tan descomunal —imás de 275.000 páginas, así como lo oye! - como original: Leibniz. Pero lo más interesante del caso era la pregunta que atravesaba el curso: ¿qué modernidad conoceríamos hoy en el caso de que esta hubiese seguido la ruta leibniziana? Recuérdese que en los textos de historia de la filosofía, los dos autores citados comparten cartel y lo que aquí se venía a cuestionar era si podían hacerlo. La respuesta obviamente era que no. El doctor Nicolás comenzó por demostrar la parcialidad de las muchas lecturas que de la obra de ese genio se habían realizado, unas desatinadas $y$ otras muy atinadas pero, a la vez, muy incompletas, entre ellas la de Zubiri. Si se leen las páginas que éste genial filósofo dedica a Leibniz creerá que la lógica y las matemáticas ocupan el centro de la filosofía de Leibniz, como ocurre con Descartes, y nada más lejos de la realidad: es la biología $y$, además, en algunos momentos incluso la mística. Y esto Leibniz. Y permítanme otra pregunta: iy si hubiese seguido la ruta de Spinoza y todo ese magnífico juego de pasiones, intensidades, etc.? La obra de Deleuze, considerado como posmoderno, no se sostiene sin el pensamiento espinoziano. No creo por todo esto que la modernidad pueda ser definida en bloque. ¿Qué decir entonces de la posmodernidad?

Pues lo mismo. La ausencia de metarrelatos es un arma de doble filo, bien porque puede entenderse como una dispensa de la razón o como el mayor desafío que se le ha planteado nunca. En el primer caso, no hay mucho que decir porque Sobrino pone el dedo en la Ilaga. En el segundo, sin embargo, el asunto cambia, y es que la razón se autocuestiona sin miramientos, sospecha de su alcance y además lo hace en una atmósfera bastante más cargada que la de Kant porque éste ni barruntó la cota de barbarie, horror, terror y deshumanización que lamentablemente alcanzaríamos en el siglo XX. El pensamiento débil ${ }^{1}$ no es un pensamiento cobar-

Felizmente G. Vattimo ya nos visitó. 
de, timorato, no comprometido, es un pensamiento que así se autoproclama después de haber visto los resultados a los que nos condujo un pensamiento "fuerte" que se creyó omnipotente, que pecó de orgullo y desmesura. En cuanto a la utopía, ésta no es despreciada, sino valorada en lo que es, algo por lo que vale luchar día a día porque no se entiende como estado definitivo sino como liberación a conquistar, léase por ejemplo, la original obra del portugués Santos, en la que el reconocimiento de la dignidad humana sin ninguna exclusión se erige como punto de partida de cualquier reflexión ulterior.

Vayamos cerrando.

\section{Epílogo para "idiotas"}

"El mundo al revés premia al revés: desprecia la honestidad, castiga el trabajo, recompensa la falta de escrúpulos y alimenta el canibalismo."

“¿Será esta libertad, libertad de elegir entre esas desdichas amenazadas, nuestra única libertad posible? El mundo al revés enseña a padecer la realidad en lugar de cambiarla, a olvidar el pasado en lugar de escucharlo y a aceptar el futuro en lugar de imaginarlo: así practica el crimen, y así lo recomienda. En su escuela, escuela del crimen, son obligatorias las clases de impotencia, amnesia y resignación. Pero está visto que no hay desgracia sin gracia, ni cara que no tenga su contracara, ni desaliento que no busque su aliento. Ni tampoco hay escuela que no encuentre su contraescuela."

He comenzado con un prólogo para "idiotas" y lo mejor es concluir estas líneas con un epílogo para ellos, y qué mejor que comenzarlo con unas líneas del considerado como su máxima expresión: Eduardo Galeano.

El escritor uruguayo denuncia un mundo al revés y tanto Luis de Sebastián como Jon Sobrino persisten en la denuncia, de ahí que deban ser considerados como dos "idiotas". Claro, que si estamos en un mundo al revés, el significado de las palabras también cambiará, así que en un mundo al derecho tendrían que ser considerados como inteligentes, y además, como inteligentes-sentientes, pues ésta es la forma humana de vivir y de vivir con mayúsculas.

Si todavía queda algún lector que haya Ilegado hasta aquí, habrá notado que no me he detenido en el lenguaje de Luis de Sebastián y esto es así porque es el que emplea un científico social, es el que todos conocemos. Un científico social que utiliza la economía como trampolín para ir más allá y es que los números ayudan pero no lo son 
todo, pues tras ellos siempre hay una interpretación, y en ésta encuentran su verdadera función. Hay sin embargo algo que no debería pasar inadvertido: el concepto de "pecado" que aparece en el título. Deténganse en estas palabras de Sobrino.

"Lo que niega la utopía no es su ausencia, o el todavía - no, sino la activa presencia del pecado en el mundo, que configura al mundo como antirreino, el ciertamenteno. Antes se lo tomaba en serio y se aclaraba que pecado es lo que da muerte, lo que dio muerte al hijo de Dios y lo que sigue dando muerte a los hijos e hijas de Dios."

"Lo que a tu prójimo hicieres, a mí me lo haces". Este concepto de "pecado" es, en mi opinión, el puente que liga estos dos textos, el que permite que la lectura de uno de ellos se complete con la del otro, de ahí esos dos lenguajes, muy diferentes y a la vez gratamente armoniosos.

África es el pecado de Europa porque representa el antirreino del primer mundo, la distopía; lo que, aunque se quiera silenciar, sigue hablando; es lo que todavía hoy da muerte, razón por la cual nadie quiere mirarse en ese desdichado continente. África nos recuerda que el estado de excepción es el estado de normalidad en el que viven muchísimas víctimas, de ahí que en la "escuela del mundo al revés" una de las materias más importantes que se cursan sea la de AMNESIA.

Hay un fragmentito en el prólogo del libro de Sobrino que he dejado para el final:

En negativo, me abruma que, al parecer nadie se responsabiliza de cómo está nuestro inhumano mundo.

Ésta es la demostración más palmaria de que Sobrino no tiene la obra de Hayek entre sus libros de cabecera y de que no quiere vivir en el mundo al revés. ¿Quién se va a responsabilizar si el mundo vive en un orden espontáneo permanente? Cada individuo, cada átomo "racional", el "homo economicus", toma sus decisiones, decisiones que no van más allá de la maximización de su utilidad, y luego el mercado, un señor al que nadie ha visto, le premia o le castiga. $\mathrm{Y}$ si alguien considera que la acción humana va más allá de esto le recomiendo que eche un simple vistazo a la obra fundamental de Von Mises, colega de Hayek, que lleva por título La acción humana, y por subtítulo Tratado de economía. La única acción racional es la económica, ahí queda eso.

Claro que Jon Sobrino cree que la historia es apropiación de posibilidades y eso es un "grave error" porque en la "escuela del mundo al revés", como nos recuerda Galeano, las otras dos materias fuertes 
que se cursan son la IMPOTENCIA y la RESIGNACIÓN.

Otro punto que debe quedar claro es que el pensamiento hegemónico es completamente alérgico a cualquier tipo de constructivismo sea del tipo que sea. Cualquier intervención, cualquier plan, cualquier paquete de medidas que se adopten para paliar una situación no deseada tiene en el mejor de los casos efectos nulos, y en el peor, catastróficos, de ahí que se le pida al Estado que intervenga siempre que el orden espontáneo esté en peligro. ¿Por qué? Pues porque el conocimiento humano es débil, parcial, siempre escaso, y no puede hacerse plenamente cargo de una realidad que siempre lo supera, por tanto, abstención. Y aquí sí tiene razón, a mi juicio, Jon Sobrino, porque este pensamiento que aparenta prudencia es conformista, es el pensamiento de la impotencia y de la resignación.

En resumen, estamos ante dos obras importantes, estimulantes y complementarias. Imprescindibles. Dos obras de divulgación que no caen nunca por ello ni en la deformación ni en la vulgarización. Los lenguajes son diferentes pero la claridad expositiva es la misma, así como la denuncia a la que apuntan: la deshumanización. Una deshumanización que no ataca al sujeto como sustancia, sino como forma, pues como bien apunta Patxi Lanceros comentado a Foucault,

El sujeto es forma, relación consigo mismo y con los otros que se constituye en ámbitos epistémicos, políticos y morales en los que el individuo hace la experiencia de sí mismo, de su pensamiento y de su acción.

La deshumanización sería entonces un ataque a las posibilidades de transformación, de metamorfosis. La deshumanización sería la cosificación, la peor de las muertes, pues es muerte en vida.

Esto lo escribía Antonio Machado para un ilustre maestro, Francisco de Icaza, vaya también para Jon Sobrino y Luis de Sebastián.

De su raza vieja tiene la palabra corta, honda la sentencia.

Como el olivar, mucho fruto lleva, poca sombra da. 